\title{
ANILS AS POSSIBLE ANTIFERTILITY AGENTS
}

\author{
B. GAIND AND V. S. MATHUR \\ Department of Pharmacology, Postgraduate Institute of Medical \\ Education and Research, Chandigarh, India \\ (Received 10th November 1971, accepted 5th April 1972)
}

\begin{abstract}
Summary. A series of five anils and a phenylamine derivative of one of them have been tested for antifertility effect in female albino rats at a daily dose of $20 \mathrm{mg} / \mathrm{kg}$ administered orally from Days 1 to 7 of pregnancy. It was found that $\mathrm{N}$-(2-chloro-l-naphthylidene)-3-amino-2:6lutidene inhibited fertility in nine out of ten animals. The mechanism of action of this compound and the structure/action relationship of the present series of anils is discussed.
\end{abstract}

\section{INTRODUCTION}

Anils are intermediates in the synthesis of 12-azasteroids. They are the condensation products of aldehydes and amines with the loss of water.

A series of five anils and a phenylamine derivative of the first compound were obtained and these were screened for antifertility activity in female rats. The compound showing maximum antifertility activity was further studied for its mechanism of action, antiovulatory activity in female rabbits and acute toxicity in rats. A study of the structure/action relationship of these compounds in connection with their antifertility activity has also been attempted.

\section{MATERIALS AND METHODS}

Antifertility effect in female rats

The technique followed was the same as that described by Gaind \& Mathur (1971). Female rats of known fertility belonging to the Charles Foster strain were used. Every evening, vaginal smears were examined and those females which were in pro-oestrus or early oestrus were kept overnight with males of proven fertility. The presence of thick clumps of spermatozoa in the vaginal smear was taken to indicate Day 1 of pregnancy. The compounds to be tested were given orally from Days 1 to 7 of pregnancy, the daily dose being $20 \mathrm{mg} / \mathrm{kg}$ in an alcoholic suspension. The control rats received the vehicle only. Laparotomy was performed on Day 10 and the number of implants was recorded.

The mechanism of action of compound N-(2-chloro-1-naphthylidene)-3amino-2:6 lutidene, which showed maximal antifertility effect, was studied on three groups of five rats each. The compound was given to the first group from Days 1 to 3 , to the second group from Days 3 to 5 and to the third group from 
Days 5 to 7 . The daily dose was $20 \mathrm{mg} / \mathrm{kg}$ orally. Five more animals belonging to the second group were given the compound.

\section{Antiovulatory activity in rabbits}

The technique followed was the same as that described by Khanna \& Chaudhury (1968).

Adult female rabbits weighing 1.5 to $2 \mathrm{~kg}$ were isolated for 3 weeks and then allotted to two groups-the controls and the 'test' animals. The 'test' animals were given $\mathrm{N}$-(2-chloro-l-naphthylidene)-3-amino-2:6-lutidene for 2 days as an alcoholic suspension by gavage through a soft rubber catheter in a daily dose of $20 \mathrm{mg} / \mathrm{kg}$ (five animals) and $40 \mathrm{mg} / \mathrm{kg}$ (two animals). The controls (five animals) received the vehicle only. On the 3 rd day, ovulation in both the groups was induced with copper acetate $(4.0 \mathrm{mg} / \mathrm{kg})$. To ascertain whether ovulation had occurred, laparotomies were carried out $48 \mathrm{hr}$ after the copper acetate injection and the bleeding points on each ovary were noted.

\section{Acute toxicity test}

Compound N-(2-chloro-l-naphthylidene)-3 amino-2:6-lutidene as an alcoholic suspension was administered orally to five rats at a dose of $100 \mathrm{mg} / \mathrm{kg}$, and the mortality rate was noted after $24 \mathrm{hr}$ and again after $48 \mathrm{hr}$. Owing to the limited supply of the compound, this test could only be carried out in five animals.

\section{RESULTS}

Antifertility activity in female rats was observed following treatment with only three of the compounds in the series (Table 1). Nine out of ten of the animals receiving $\mathrm{N}$-(2-chloro-l-naphthylidene)-3-amino-2:6-lutidene failed to become pregnant. This compound administered over different periods of gestation (Table 2) had an antifertility effect in four of the five rats in the group which received the drug from Day 3 to Day 5 of pregnancy.

The same compound did not show any antiovulatory activity when administered in a dose of $20 \mathrm{mg} / \mathrm{kg}$ to five rabbits at $40 \mathrm{mg} / \mathrm{kg}$ to two rabbits. The mean number of bleeding points in the control group of five rabbits was $5 \cdot 2$ whereas in the two treated groups, it was 5.6 and 5.5 , respectively.

In the acute toxicity test, no mortality was observed 24 or $48 \mathrm{hr}$ after the administration of the drug.

\section{DISCUSSION}

The present series of compounds screened for possible antifertility activity are intermediates in the synthesis of azasteroids. The common feature in the structures both of anils and azasteroids is the presence of a naphthalene nucleus and nitrogen.

All the five anils used in this study had a naphthalene ring substituted at position 2 by chlorine and the compound was linked to the amine nucleus by an unsaturated bond. The sixth compound was a substituted phenylamine derived by reduction from $\mathrm{N}$-(2-chloro-1-naphthylidene) aniline. 
TABLE 1

EFFECT OF ORALLY ADMINISTERED ANILS ON PREGNANCY IN RATS

\begin{tabular}{|c|c|c|c|}
\hline Compounds & Chemical structure & $\begin{array}{l}\text { No. of rats } \\
\text { pregnant/no. } \\
\text { of rats treated }\end{array}$ & $\begin{array}{c}\text { No. of implants } \\
\text { in individual } \\
\text { rats }\end{array}$ \\
\hline Control (vehicle only) & - & $10 / 10$ & $\begin{array}{l}9,11,8,7,5,7 \\
10,10,9,8\end{array}$ \\
\hline $\begin{array}{l}\mathrm{N} \text {-(2-chloro-1-naphthylidene) } \\
\text { aniline }\end{array}$ & & $4 / 5$ & $9,10,7,7$ \\
\hline $\begin{array}{l}\mathrm{N} \text {-(2-chloro-1-naphthylidene })-\mathrm{O} \text { - } \\
\text { toluidine }\end{array}$ & & $3 / 10$ & $11,7,9$ \\
\hline $\begin{array}{l}\mathrm{N} \text {-(2-chloro-1-naphthylidene)p- } \\
\text { toluidine }\end{array}$ & & $4 / 5$ & $9,8,7,7$ \\
\hline $\begin{array}{l}\mathrm{N} \text {-(2-chloro-1-naphthylidene)-3- } \\
\text { amino-2:6-lutidene }\end{array}$ & & $1 / 10$ & 12 \\
\hline $\begin{array}{l}\mathrm{N} \text {-(2-chloro-1-naphthylidene)-O- } \\
\text { anisidine }\end{array}$ & & $4 / 9$ & $9,9,11,2$ \\
\hline $\begin{array}{l}\text { (2-chloro-1-naphthyl)N-phenyl- } \\
\text { methylamine }\end{array}$ & & $4 / 5$ & $7,6,7,9$ \\
\hline
\end{tabular}

Dosage: $20 \mathrm{mg} / \mathrm{kg}$ body weight from Days 1 to 7 of pregnancy.

Substitution in the amine nucleus of $\mathrm{N}$-(2-chloro-1-naphthylidene) aniline by a methyl group at the orthoposition, as in $\mathrm{N}$-(2-chloro-l-naphthylidene)-Otoluidine, increases the antifertility activity from $20 \%$ to $70 \%$. The introduction of an O-methyl group as in $\mathrm{N}$-(2-chloro-1-naphthylidene)-O-anisidine raises the activity only to $55.5 \%$. But the introduction of aminolutidine in place of aniline,

TABLE 2

EFFEGT OF N-(2-GHLORO-1-NAPHTHYLIDENE)-3-AMINO-2:6LUTIDENE ON PREGNANCY IN RATS WHEN FED FOR DIFFERENT TIMES BETWEEN DAYS 1 AND 7 OF PREGNANCY

\begin{tabular}{c|c|c}
\hline Days of pregnancy & $\begin{array}{c}\text { No. of rats pregnant/ } \\
\text { no. of rats treated }\end{array}$ & $\begin{array}{c}\text { No. of implants in } \\
\text { individual rats }\end{array}$ \\
\hline 1 to 3 & $4 / 5$ & $4,10,7,9$ \\
5 to 7 & $4 / 5$ & $6,9,5,2$ \\
3 to 5 & $2 / 10$ & 4,7 \\
\hline
\end{tabular}

Dosage: $20 \mathrm{mg} / \mathrm{kg}$ body weight. 
as in $\mathrm{N}$-(2-chloro-1-naphthylidene)-3-amino-2:6-lutidene, produces the maximum antifertility effect $(90 \%)$.

When N-(2-chloro-1-naphthylidene)-3-amino-2:6-lutidene was administered to three groups of pregnant female rats for different periods of time (Table 2), maximum antifertility activity was observed in the group which received the drug on Days 3 to 5 of pregnancy. No significant reduction in the number of implants was seen in the other two groups which received the drug from Days 1 to 3 of pregnancy or Days 5 to 7 of pregnancy. The compound did not show any antiovulatory activity when tested in rabbits. It therefore appears that $\mathrm{N}$-(2-chloro-1-naphthylidene)-3-amino-2:6-lutidene acts mainly as an antiimplantation agent in rats.

\section{ACKNOWLEDGMENTS}

We are grateful to Dr S. V. Kessar and Mr G. S. Joshi of the Chemistry Department of the Punjab University, Ghandigarh, who synthesized these compounds. The project has been financed in part by a grant made by the United States Department of Agriculture, Agriculture Research Services, under PL-480.

\section{REFERENGES}

Gaind, B. \& MathuR, V. S. (1971) Antifertility effects in rats of (some) compounds related to azasteroids. F. Reprod. Fert. 27, 459.

KhANNA, U. \& CHAUdHURY, R. R. (1968) Rapid screening of possible antiovulatory substances using copper induced ovulation. Indian F. Pharm. 30, 148. 